\title{
Assessment of nutritional status of children with portal hypertension
}

\section{Ocena stanu odżywienia u dzieci z nadciśnieniem wrotnym}

\author{
Jarosław Kierkus ${ }^{1}$, Grzegorz Oracz ${ }^{1}$, Sylwia Szymanska², Edyta Szymanska², Michał Szczepanski', Józef Ryżko ${ }^{1}$ \\ 1Department of Gastroenterology, Hepatology and Immunology, The Children's Memorial Health Institute, Warsaw, Poland \\ 2Medical University of Warsaw, Poland
}

Przegląd Gastroenterologiczny 2011; 6 (3): 146-153 DOI: $10.5114 / p g .2011 .22797$

Key words: portal hypertension, liver cirrhosis, malnutrition, children.

Słowa kluczowe: nadciśnienie wrotne, marskość wątroby, niedożywienie, dzieci. Address for correspondence: Jarosław Kierkuś MD, Department of Gastroenterology, Hepatology and Immunology, The Children's
Memorial Health Institute, 20 Al. Dzieci Polskich, 04-730 Warsaw, Poland, phone/fax +48 2281573 92, e-mail: j.kierkus@czd.pl

\begin{abstract}
Introduction: Assessment of nutritional status of children with portal hypertension is an important prognostic factor which plays a significant role in the efficacy of their treatment.

Aim: To assess the nutritional state of paediatric patients with portal hypertension through various methods of nutritional assessment and to investigate the usefulness of the techniques.

Material and methods: The study group included 31 children with portal hypertension classified into 3 subgroups: patients with portal vein obstruction, biliary cirrhosis and post-hepatitic cirrhosis. The following anthropometrics data were measured: weight, body mass index (BMI), Cole's index and body mass rate (BMR). The body fat (BF) and fatfree mass (FFM) were measured by skin fold bioelectrical impedance assessment (BIA) and dual-energy X-ray absorptiometry (DEXA). The total body water percentage (TBW\%) and extracellular fluid content were measured by bioelectrical impedance (BIA). Laboratory parameters such as albumins, cholesterol, vitamin levels (A, E and D), and trace elements $(\mathrm{Fe}, \mathrm{Zn})$ together with other biochemical markers were also assessed. The control group consisted of healthy children selected according to their age.

Results and conclusions: Malnutrition, based on Cole's index and $\mathrm{BMI}<10^{\text {th }}$ percentile, was detected in $60 \%$ of children with biliary cirrhosis, $55.5 \%$ of those with posthepatitic cirrhosis and $45.5 \%$ of those with portal vein obstruction, respectively. Fat-free mass, measured by different methods, remained stable in each group $(r=0.97)$. For $\mathrm{BF}$, the correlation between anthropometry, BIA and DEXA was significantly lower. Total body water percentage was higher in children with biliary cirrhosis than in other groups $(p<0.05)$. Vitamin A concentration was decreased in each
\end{abstract}

\section{Streszczenie}

Wstęp: Stan odżywienia u dzieci z nadciśnieniem wrotnym odgrywa ważną rolę w skuteczności terapii oraz rokowaniu. Bardzo ważne znaczenie ma wczesne wykrycie zaburzeń stanu odżywienia i odpowiednie leczenie żywieniowe w tej grupie pacjentów.

Cel: Ocena stanu odżywienia u dzieci z nadciśnieniem wrotnym z zastosowaniem różnych metod, a także określenie ich przydatności w diagnostyce.

Materiał i metody: Grupę badaną stanowiło 31 dzieci z nadciśnieniem wrotnym, które podzielono na 3 podgrupy, w zależności od etiologii choroby: pacjentów z blokiem przedwątrobowym, marskością żółciowa oraz marskościa pozapalną. We wszystkich grupach wykonano następujące badania: pomiary antropometryczne (masa ciała i wysokość), wskaźnik masy ciała (BMI), wskaźnik Cole’a i wspótczynnik masy ciała (WMC). Dodatkowo u wszystkich obliczono beztłuszczową masę ciała (BMC) oraz masę tłuszczową na podstawie pomiaru 4 fałdów skórnych (nad mięśniami: dwugłowym, trójgłowym oraz pod topatką i nad kolcem biodrowym). Oceny dokonano metodą bioelektrycznej analizy impedancji (BIA) oraz metodą podwójnej absorpcji promieniowania X (DEXA). Zawartość wody całkowitej (CW) i wody zewnątrzkomórkowej (ZW) w organizmie oszacowano metodą bioelektrycznej analizy impedancji (BIA). Wykonano również badania laboratoryjne z krwi: oznaczenie stężenia albumin, cholesterolu, witaminy A i E, 25-hydroksycholekalciferolu oraz pierwiastków śladowych (Fe, Zn). Grupę kontrolną stanowity zdrowe dzieci w podobnym przedziale wiekowym.

Wyniki i wnioski: Niedożywienie, opierając się na wskaźnikach Cole'a i BMI < 10. percentyla, zidentyfikowano u $60 \%$ dzieci z marskością żótciową, 55,5\% z marskością pozapalną i 45,5\% z blokiem przedwątrobowym. Oceniając BMC różnymi metodami, uzyskano zbliżone wyniki, nieróżniące się staty- 
group (the lowest in children with biliary cirrhosis). No correlation between aminotransferase concentration and nutritional state was found.

\section{Introduction}

Portal hypertension refers to abnormally high pressure in the hepatic portal vein. It is defined as a portal pressure of $12 \mathrm{mmHg}$ or more (compared with the normal $5-10 \mathrm{mmHg}$ ) [1]. A consequence of the obstruction through the portal vein is the development of collateral circulation. Portal hypertension can occur in children with any type of chronic liver disease which causes cirrhosis (intrahepatic blood flow obstruction) or in those with portal vein thrombosis leading to its obstruction (extrahepatic portal hypertension). Portal hypertension may affect intestinal function leading to malnutrition in children with liver disease. Other causes of the pathological state are: increased energy expenditure, decreased food intake and metabolic derangements [2]. It is crucial to maintain proper nutritional status in patients awaiting liver transplantation as it has an influence on their growth before the intervention and determines the prognosis after the operation [3]. However, reliable assessment of nutritional status in patients with portal hypertension is difficult, as basic nutritional measurements, such as body mass and height, are not sufficient parameters because of the water retention and ascites frequently found in those patients. In those cases it is essential to assess the body constitution by body fat (BF), fat-free mass (FFM) and water content measurements. Fat-free mass and BF are measured by anthropometric skin fold measurements and dual-energy X-ray absorptiometry (DEXA), while bioelectric impedance assessment (BIA) also enables water content assessment.

\section{Aim}

This study aimed to assess the nutritional state of paediatric patients with portal hypertension using various methods of nutritional assessment and to investigate the usefulness of these diagnostics.

\section{Material and methods \\ Patients}

This study included 31 children with diagnosed portal hypertension, hospitalized in the Department of Gastroenterology, Hepatology and Immunology, Children's stycznie między poszczególnymi metodami $(r=0,97)$. W przypadku masy tłuszczowej korelacje były znacząco mniejsze. Największą zawartość wody całkowitej stwierdzono u dzieci z marskością żółciową. Stężenie witaminy było mniejsze u wszystkich dzieci z nadciśnieniem wrotnym, zwłaszcza w grupie z marskością żółciową. Nie wykazano zależności wykładników stanu zapalnego od parametrów czynności wątroby u dzieci z nadciśnieniem wrotnym.

Memorial Health Institute, Warsaw, Poland. The study was accepted by the Bioethical Commission. Diagnosis was based on portal hypertension manifested by oesophageal varices and obstruction to the flow of the portal vein detected in ultrasonography. Children with intrahepatic disorders (liver cirrhosis) also had history of liver biopsy taken in order to determine disease aetiology.

Patients were divided into 3 subgroups:

- those with portal vein obstruction (extrahepatic portal hypertension);

- those with obstruction to flow on the basis of a biliary tract disease (biliary cirrhosis);

- those with obstruction to flow on the basis of chronic hepatitis (post-hepatitic cirrhosis).

Laboratory tests were carried out during one of the patient's numerous hospitalizations. Inclusion criteria were: portal hypertension, A or B children's group in patients with liver cirrhosis (those in group $C$ were excluded), age 5-18 years. Written informed consent was obtained from parents or children's legal guardians before the study commencement.

\section{Description of study groups}

Group 1 - patients with portal hypertension on the basis of portal vein obstruction

Diagnosis was confirmed by Doppler flow ultrasonography and the presence of oesophageal varices in endoscopy. This group consisted of 11 patients ( 6 males and 5 females) aged $11.5 \pm 4.0$ years.

\section{Group 2 - patients with portal hypertension on the basis of a biliary tract disease}

Intrahepatic obstruction to flow was confirmed by Doppler flow ultrasonography, liver cirrhosis by histopathological examination (biopsy). Presence of oesophageal varices was supplementary evidence of portal hypertension. This group consisted of 11 patients ( 6 males and 5 females) aged $11.2 \pm 3.5$ years.

\section{Group 3 - patients with portal hypertension due to} $H B V$ infection

Intrahepatic obstruction to flow was confirmed by Doppler flow ultrasonography, liver cirrhosis by histopathological examination (biopsy). Presence of oeso- 
phageal varices was supplementary evidence of portal hypertension. This group consisted of 9 patients ( 8 males and 1 female) aged $13.4 \pm 4.3$ years.

\section{Description of control groups}

The control group was classified into three subgroups consisting of healthy children selected from Warsaw schools according to their age. Group $1-336$ healthy children to have FFM and BF measured by DEXA method. The mean value of FFM and BF was estimated for each age group. Group 2 - 9 healthy children aged $9.7 \pm 2.7$ to have FFM and BF measured by BIA method. Group $3-9$ healthy children aged $9.7 \pm 2.7$ to have total body water percentage (TBW\%) and amount of extracellular fluid assessed by BIA.

\section{Methods}

All participants underwent the following examinations:

\section{Anthropometry}

Each individual child had height and weight accurately measured on scales (ZALiMP, Warsaw), in hospital, in the morning in the fasting state. The results were compared to standard charts (height/weight for age) and percentile values were determined. To make the results more objective, the following parameters were assessed additionally:

- body mass index (BMI) based on height and weight: mass $(\mathrm{kg}) /$ height $^{2}\left(\mathrm{~m}^{2}\right)$; results were compared to standard charts for the age;

- Cole's index to calculate the sensitivity, specificity and agreement of BMI; patient's BMI/standard BMI (50th percentile for body mass $/ 50^{\text {th }}$ percentile for height concerning age and sex);

- body mass rate (BMR) - BMI multiplied by body surface area:

$$
B M R=M^{1.425} \times 71.84 / L^{1.275},
$$

where: $M$ - body mass $(\mathrm{kg}), \mathrm{L}$ - length $(\mathrm{cm})$.

The results were compared to standards for age and sex. Abnormal results were those below the low normal range;

- BF and FFM were assessed using 3 different methods:

- measurement of skin folds using apparatus by Holtan Ltd., UK; for FFM the method modified by Ksiazyk [4] was applied:

- males below 11 years old:

LBM (lean body mass $)=\{100-[(4.95 /(1.169-0.0788 \times$ $\log \mathrm{F})-4.5) \times 100]\} \times \mathrm{MC} / 100$

- males above 11 years old:

$L B M=\{100-[(4.95 /(1.1533-0.0643 \times \log F)-4.5) \times$ $100]\} \times M C / 100$
- females below 11 years old:

$L B M=\{100-[(4.95 /(1.2063-0.0999 \times \log F)-4.5) \times$ $100]\} \times M C / 100$

- females above 11 years old:

$L B M=\{100-[(4.95 /(1.1369-0.0598 \times \log F)-4.5) \times$ $100]\} \times M C / 100$,

where: $M C$ - body mass (kg), F - sum of four skin folds (mm).

The values of BF and FFM were presented in the mean percentage for control group matched according to age and sex;

- BIA: whole-body BIA measurements were taken using two types of apparatus, MALTRON BF-905 (Maltron LTD, Essex, UK) and BODYSTAT 5000 (Bodystat Limited, Douglas, UK). All subjects were asked to lie in the supine position with legs apart (so as not touching at the thighs) and arms away from the body (so as not touching the torso). The measurement was taken in the morning on an empty stomach with four surface electrodes placed on the right ankle and wrist. An alcohol swab was used to clean all electrode sites prior to measurement. Fat-free mass was assessed using the index of Houtkooper et al. [5]:

$$
L B M=0.58 \times L^{2} / R+0.24 M+2.69
$$

where: L - length (cm), R - impedance (ohms), $M$ - body mass $(\mathrm{kg})$;

- DEXA - X-rays of two different energies were used to scan the body, one of which was absorbed more strongly by fat than the other. A computer subtracted one image from the other, and the differences indicated the amount of fat relative to other tissues at each point. The sum over the entire image enabled calculation of the overall body composition. During the examination all subjects were asked to lie in the supine position. The amounts of BF and FFM were presented in the mean percentage for the control group matched according to age and sex.

Total body water percentage (TBW\%) and amount of extracellular fluid using bioelectrical impedance (BIA)

During the examination all subjects were asked to lie in the supine position and spot electrodes were placed on the hands and bare feet. Electrolyte gel was applied first, and then a current of $50 \mathrm{kHz}$ was introduced.

\section{Laboratory tests}

Laboratory tests were carried out to estimate the nutritional state of children and function of their livers. Each patient had a blood sample taken in the morning, 
before breakfast, and the following markers were assessed: albumins, cholesterol, retinol (vitamin A), $\alpha$-tocopherol (vitamin E), 25-hydroxycholecalciferol $\left(25(\mathrm{OH}) \mathrm{D}_{3}\right)$, trace elements such as iron and zinc, total and conjugated bilirubin, INR, alanine aminotransferase activity and $\gamma$-glutamyl transpeptidase.

\section{Statistical analysis}

The analysis was done using StatsDirect Statistical Software, version 2, 2, 8 (StatsDirect Ltd., Cheshire, $U K)$. All values in the text refer to mean \pm standard error of the mean $( \pm$ SEM). The amounts of BF and FFM were not normally distributed so they were presented as a medians within the range. Between group comparisons were made using $\chi^{2}$ test (Fisher-Freeman-Halton), as appropriate. The small number of groups $(<5)$ was the reason for choosing this test. Comparison between means was assessed by ANOVA test for data distributed normally. For data not distributed normally, comparisons were made with the Mann-Whitney U-test (when $p<0.05$ ) or Kruskal-Wallis test (when appropriate). A value of $p<0.05$ was accepted as statistically significant. Linear regression analysis was used to determine the changes in FFM and BF measured by different methods.

\section{Results}

\section{Anthropometric data}

Malnutrition, based on $<10^{\text {th }}$ percentile, was detected in $54.5 \%$ of children with biliary cirrhosis, $44.4 \%$ with post-hepatitic cirrhosis and $9 \%$ with portal vein obstruction, respectively. Malnutrition, based on $\mathrm{BMI}<10^{\text {th }}$ percentile (Figure 1) and Cole's index (Table I) was detected in $60 \%$ of children with biliary cirrhosis, $55.5 \%$ with post-hepatitic cirrhosis and $45.5 \%$ with portal vein obstruction, respectively.

Fat-free mass and BF measured by different methods were comparable. Fat-free mass in children with biliary cirrhosis was lower than in control groups, but no statistically significant differences were found among the study groups. Body fat was decreased in all examined children, but in children with biliary cirrhosis was significantly lower than in control groups (BIA) and in patient with post-hepatitic cirrhosis or portal vein obstruction (DEXA). There was a high correlation ( $r=0.97$ for all groups) between FFM measured by BIA (Figure 2) and DEXA (Figure 3). The correlation between anthropometry and DEXA was slightly lower $(r=0.88$ for biliary cirrhosis; $r=0.95$ for post-hepatitic cirrhosis or portal vein obstruction, respectively). For BF, the correlation between BIA (Figure 4) and DEXA (Figure 5) was lower ( $r=0.87$ for biliary and posthepatitic cirrhosis; $r=0.97$ for portal vein obstruction, respectively) and between anthropometry and DEXA significantly lower ( $r=0.69$ for biliary cirrhosis; 0.76 for post-hepatitic cirrhosis and 0.87 for portal vein obstruction, respectively) than results for FFM.

Total body water percentage and amount of extracellular fluid using bioelectrical impedance

Total body water percentage was significantly higher in all study groups than in healthy children. No statistically significant differences were detected among the study groups. Results measured by the two different apparatus were comparable, with no statistically significant differences. The content of extracellular fluid was higher in children with biliary and post-hepatitic cirrhosis than in control groups $(p<0.05)$. Additionally, the

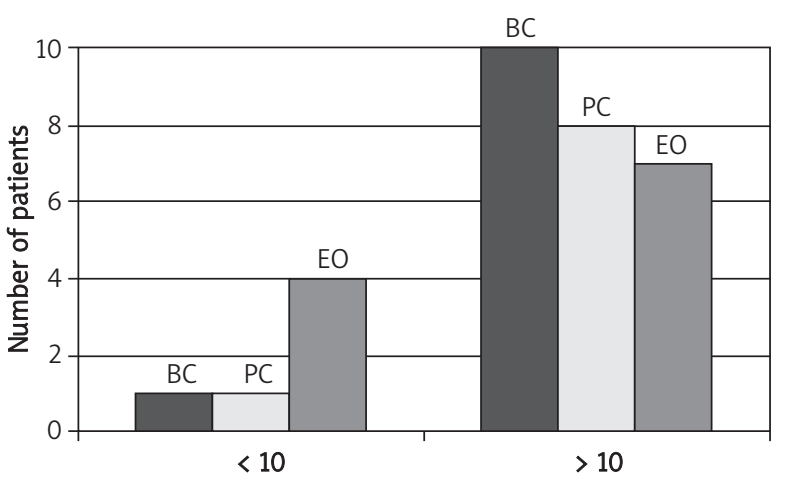

$B C$ - biliary cirrhosis, $P C$ - post-hepatitic cirrhosis, EO - extrahepatic obstruction

Fig. 1. Malnutrition based on BMI in study groups Ryc. 1. Ocena niedożywienia na podstawie wspótczynnika BMI u analizowanych dzieci

Table I. Malnutrition based on Cole's index in study groups

Tabela I. Ocena niedożywienia na podstawie wskaźnika Cole'a u analizowanych dzieci

\begin{tabular}{cccc} 
& $\begin{array}{c}\text { Number of children } \\
\text { with biliary cirrhosis }\end{array}$ & $\begin{array}{c}\text { Number of children } \\
\text { with post-hepatitic cirrhosis }\end{array}$ & $\begin{array}{c}\text { Number of children } \\
\text { with portal vein obstruction }\end{array}$ \\
\hline$<85 \%$ & 3 & 2 & 3 \\
\hline$>85 \%$ & 8 & 7 & 8
\end{tabular}

$<85 \%$ - malnutrition, $>85 \%$ - normal nutritional state 


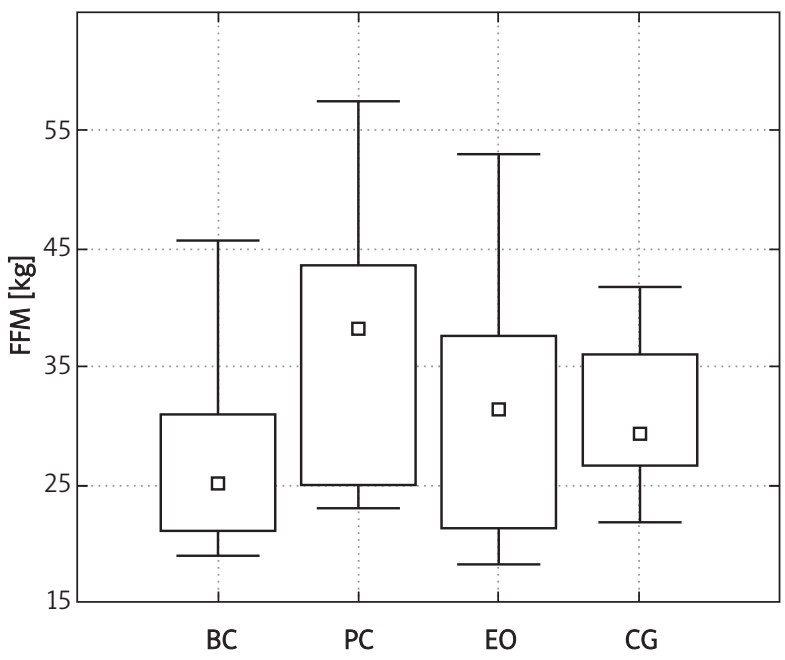

$B C$ - biliary cirrhosis, $P C$ - post-hepatitic cirrhosis, EO - extrahepatic obstruction, $C G$ - control group

Fig. 2. Comparison of FFM in study groups and control group measured by BIA method (Maltron apparatus)

Ryc. 2. Zawartość BMC w porównaniu z zawartościa $w$ grupie kontrolnej mierzona metodą bioimpedancji elektrycznej (aparat Maltron)

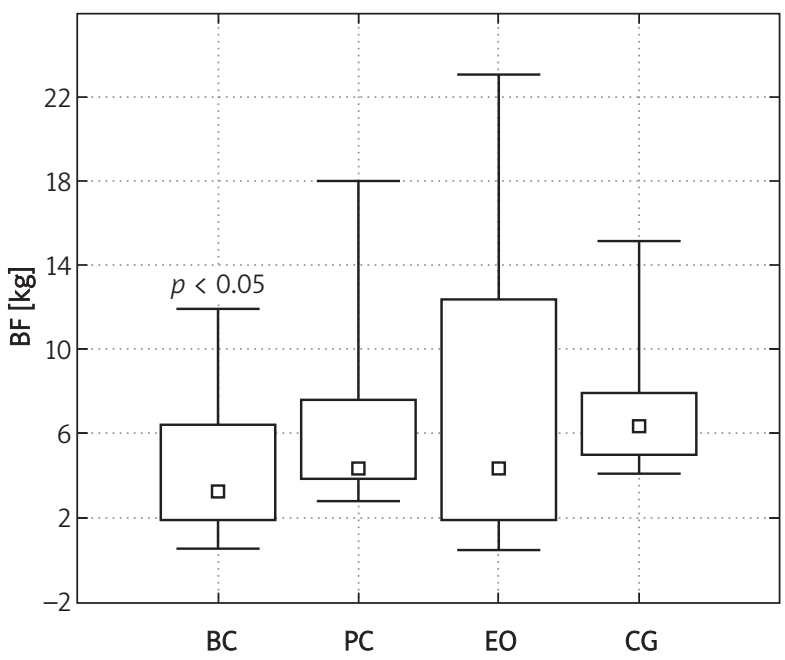

$B C$ - biliary cirrhosis, $P C$ - post-hepatitic cirrhosis, EO - extrahepatic obstruction, $C G$ - control group

Fig. 4. Comparison of BF in study groups and control group measured by BIA method (Maltron apparatus)

Ryc. 4. Zawartość masy tłuszczowej ciała w porównaniu z zawartościq w grupie kontrolnej mierzona metoda bioimpedancji elektrycznej (aparat Maltron)

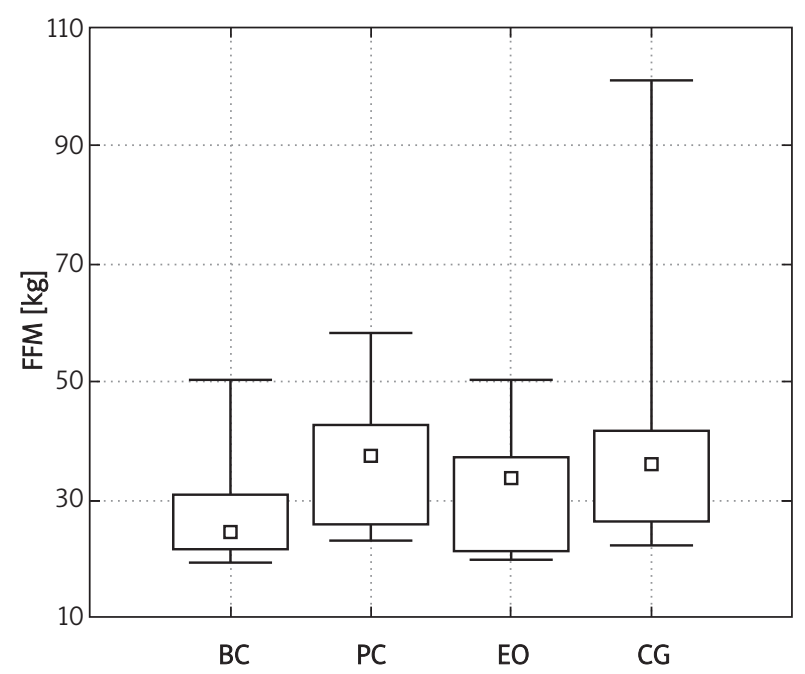

$B C$ - biliary cirrhosis, $P C$ - post-hepatitic cirrhosis, EO - extrahepatic obstruction, CG - control group

Fig. 3. Comparison of FFM in study groups and control group measured by BIA method (Bodystat 5000 apparatus)

Ryc. 3. Zawartość BMC w porównaniu z zawartościa $w$ grupie kontrolnej mierzona metoda bioimpedancji elektrycznej (aparat Bodystat 5000)

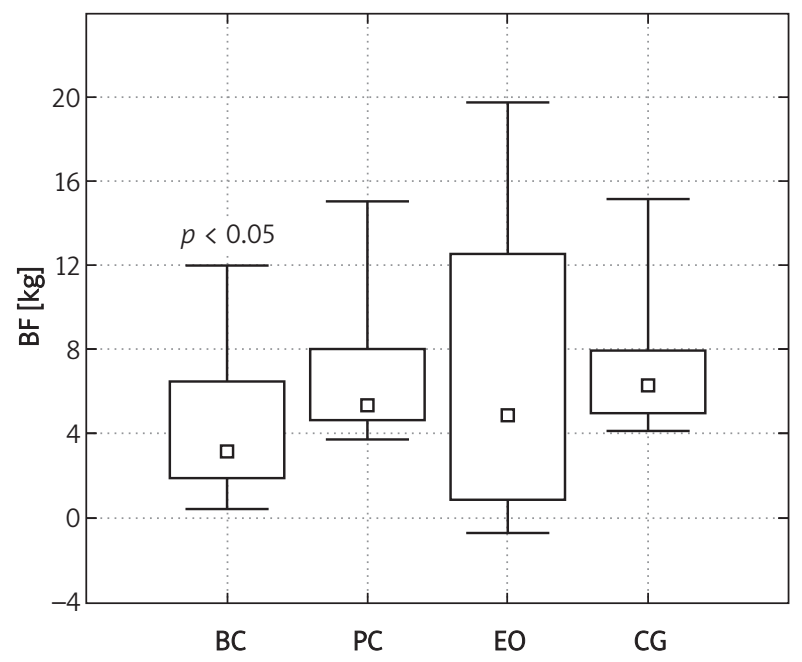

$B C$ - biliary cirrhosis, $P C$ - post-hepatitic cirrhosis, EO - extrahepatic obstruction, CG - control group

Fig. 5. Comparison of BF in study groups and control group measured by BIA method (Bodystat 5000 apparatus)

Ryc. 5. Zawartość masy tłuszczowej ciała w porównaniu z zawartościa w grupie kontrolnej mierzona metoda bioimpedancji elektrycznej (aparat Bodystat 5000) 
results detected in patients with liver cirrhosis were significantly higher than in patients with portal vein obstruction. No statistically significant differences were found among children with biliary and post-hepatitic cirrhosis.

The percentage of extracellular fluid in total body water was higher in children with biliary cirrhosis than in other groups $(p<0.05)$ (Figure 6$)$. No statistically significant differences were found among other groups.

\section{Laboratory data}

Retinol (vitamin A) concentration was decreased in each group, and was the lowest in children with biliary cirrhosis. No correlation between the aminotransferase concentration and nutritional state was found. Table I shows the exact values of each laboratory parameter.

\section{Discussion}

Medical examination together with body mass and height measurement are still regarded as the most appropriate methods of assessing the patient's nutritional state. However, these parameters are adequate only in healthy people and patients with no disorders of body components such as oedema or ascites. Assessment of nutritional state in children is even more complicated, as their growth rate depends not only on developmental age, but also on higher nutrient and energy demands. Thus, the risk of malnutrition and its clinical consequences is more common and dangerous in paediatric patients, specially in those with liver disorders. Numerous studies have shown that children with liver disorders are particularly at risk of malnutrition because of their higher energy expenditure [6-9] and diminished intake. It is also known that improvement of the patient's nutritional state before liver transplantation will have a positive influence on the patient's posttransplant survival [10-12]. Therefore, it is of highest importance to apply accurate and reliable methods of nutritional state assessment in order to introduce adequate treatment such as enteral nutrition, as early as possible. Oedema, ascites, hepatomegaly and splenomegaly are often found in children with liver disorders, specially in those with cirrhosis and portal hypertension, which make proper examination difficult. Therefore, while making the diagnosis it is essential to apply extended, more objective methods such as assessment of body components, including TBW\%. The aim of this study was to assess the nutritional state of children with liver disorders through different measurement methods.

Anthropometry such as height and weight analysis proved that the risk of malnutrition is higher in children with liver cirrhosis than in those with portal vein

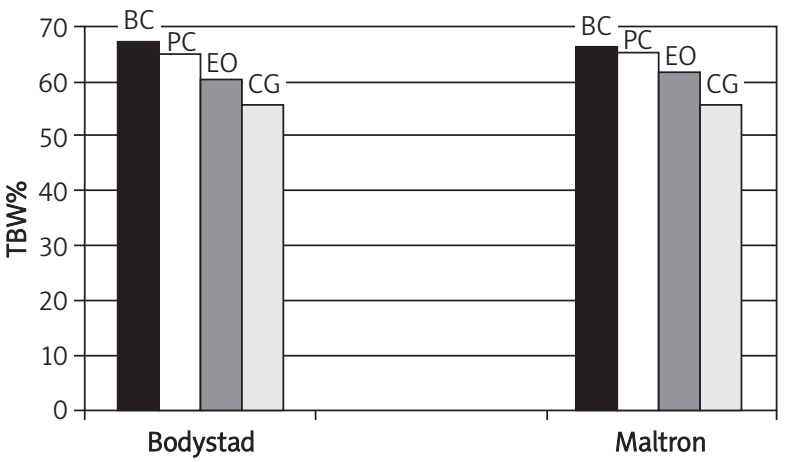

$B C$ - biliary cirrhosis, $P C$ - post-hepatitic cirrhosis, EO - extrahepatic obstruction, CG - control group

Fig. 6. Total body water percentage (TBW\%) with reference to body mass in study groups and control group measured by both apparatus (Bodystat, Maltron)

Ryc. 6. Procentowa zawartość catkowitej wody $w$ stosunku do masy ciała $w$ organizmie badanych dzieci oraz w grupie kontrolnej

obstruction - distribution of percentile $<10^{\text {th }}$ was found in $36.3 \%$ of children with biliary cirrhosis, $44.4 \%$ of post-hepatitic cirrhosis and only in $18.2 \%$ of portal vein obstruction. Additionally, most examined patients had both height and weight deficiencies. However, $\mathrm{BMI}$ analysis revealed that only 1 patient with biliary cirrhosis, 1 with post-hepatitic cirrhosis, and as many as 4 with portal vein obstruction had a decreased ( $<10$ percentile) BMI score. Those results proved that nutritional state assessment based on BMI only may lead to the incorrect conclusion that children with liver cirrhosis are not at risk of malnutrition. The proper BMI score in those patients is due to both height and weight deficiencies. Similar observations were published by Książyk [13], who also stated that BMI is not a sufficiently reliable method of nutritional state assessment in children. He proposed another indicator, WMC, that, apart from body height and weight, also includes body surface area and is very sensitive with reference to malnutrition (specially $<10^{\text {th }}$ percentile). Cole's index detected more malnourished children with biliary cirrhosis than BMI but less than BMR, which proved that WMC is the most sensitive and is therefore recommended to diagnose malnutrition in children above 4 years old.

Estimation of body composition, most commonly the BF and FFM, is also useful in nutritional state assessment. Fat-free mass and BF remained stable in the study groups except in children with biliary cirrhosis, in whom both FFM and BF declined. Our observations are in concordance with those presented in similar studies [13-15]. Another acknowledged method of nutritional state 
assessment is BIA, which enables the determination of both FFM and total body water (TBW) in subjects without significant fluid and electrolyte abnormalities [16, 17]. This method is popular owing to its ease of use, portability of the equipment and its relatively low cost compared to some of the other methods such as DEXA. In this study two types of apparatus, Maltron and Bodystat 5000 , were used to estimate patients' body composition. Fat-free mass and BF measured by BIA, DEXA and anthropometric methods were comparable but TBW percentage and amount of extracellular fluid were significantly higher in children with liver cirrhosis (both biliary and post-hepatitic) than in control groups. These results confirm Lehnert's [18] observations in adults patients with liver cirrhosis are more predisposed to body water accumulation; thus assessment of nutritional state by primary methods only is difficult.

Comparison of FFM and BF measured by different methods proved that children with biliary cirrhosis are more exposed to malnutrition. However, FFM seems to be a less sensitive indicator of malnutrition due to its correlation with fluid disorders. DEXA correlates properly with both anthropometry and BIA. BIA can be applied in patients with ascites [18-20], in whom nutritional state is difficult to estimate. Similar observations were published by Kelly [11]; in his studies, > $60 \%$ of children with biliary cirrhosis had nutritional disorders before liver transplantation. Moukarzel et al. [21] analysed the death rate in patients after liver transplantation and he found that $80 \%$ of them were malnourished. This proved that nutritional state influences patients' survival time.

The analysis of laboratory parameters reflecting patients' nutritional state showed deficiencies of fat-soluble vitamin, as a result of its malabsorption. Vitamin A deficits were found in each study group, which confirmed the reports of other authors [14, 22, 23], but vitamin $\mathrm{E}$ concentration values in our patients were proper, in contrast to most published studies [14]. Constant management of children with portal hypertension, regular monitoring and adequate vitamin supplementation may explain these results. Patients with liver cirrhosis are treated with active vitamin D metabolite (Devisol, which is better absorbed than native vitamin D) as a standard therapeutic procedure. Thereby, we reported higher 25-hydroxycholecalciferol concentration in children with biliary cirrhosis than in those with portal vein obstruction. Our analyses lead to the conclusion that nutritional deficiency is more intense in patients with biliary than post-hepatitic cirrhosis, which is associated with severe cholestasis and earlier activation of pathogenic factors.
Liver disorders lead to malnutrition, which is specially dangerous in children. Therefore, the assessment of nutritional state of patients with liver cirrhosis should be precise and objective so as to introduce proper treatment as early as possible. Anthropometry together with BIA and DEXA is very useful.

\section{Conclusions}

1. Children with portal hypertension, particularly with biliary liver cirrhosis, suffer from malnutrition, manifested by FFM decrease most frequently.

2. There is an increase of both TBW percentage and extracellular fluid content in children with liver cirrhosis (both biliary and post-hepatitic).

3. The BIA method is useful in nutritional assessment in children with portal hypertension.

4. When comparing anthropometry, BMR has the advantage over BMI and Cole's index in nutritional assessment of children with portal hypertension.

5. There is a high correlation between BIA and DEXA in LBM and MT assessment in children with portal hypertension.

6. Decrease of vitamin A serum concentration is found to be a laboratory parameter of malnutrition in children with portal hypertension, particularly in those with biliary liver cirrhosis.

7. There is no proven correlation between the nutritional status and laboratory parameters of liver function in children with portal hypertension.

\section{References}

1. McIntyre N, Burroughs AK. Cirrhosis, portal hypertension, and ascites. In: Concise Oxford Textbook of Medicine. Ledingham JGG, Warrell DA (ed.). Oxford University Press, Oxford 2000.

2. Taylor RM, Bjarnason I, Cheeseman P. Intestinal permeability and absorptive capacity in children with portal hypertension. Scand I Gastroenterol 2002; 37: 807-11.

3. Herrera MF, Hoyos C, Prado E, Orozco H. Effects of malnutrition on infective morbidity in the surgical treatment of portal hypertension (prospective evaluation). Rev Invest Clin 1991; 43: 19-24.

4. Książyk J. Propozycja nowej metody oceny stanu odżywienia. Pediatr Pol 1995; 70: 347.

5. Hautkooper LB, Lohman TG, Going SB, Hall MC. Validity of bioelectric impedance for body composition assessment in children. J Appl Physiol 1989; 66: 814.

6. Heymsfield SB, Waki M, Reinus J. Are patients with chronic liver disease hypermetabolic? Hepatology 1990; 11: 502-5.

7. Muller MJ. Hepatic energy and substrate metabolism: a possible metabolic basis for early nutritional support in cirrhotic patients. Nutrition 1998; 14: 30

8. Pierro A, Koletzko B, Carnielli V, et al. Resting energy expenditure is increased in infants and children with extrahepatic biliary atresia. J Pediatr Surg 1989; 24: 534. 
9. Książyk J, Łyszkowska M, Kierkuś J. Energy metabolism in portal hypertension in children. Nutrition 1996; 12: 469.

10. Guest JE, Hasse J. Nutritional aspects of pediatric liver transplantation. In: Transplantation of the liver. Busuttil RW, Klintmalm GB (eds.). WB. Saunders Co., Philadelphia 1996; 227.

11. Kelly DA. Nutritional factors affecting growth before and after liver transplantation. Pediatr Transplant 1997; 1: 80.

12. Lee $\mathrm{H}$, Vacanti J. Liver transplantation and its long-term management in children. Pediatr Clin North Am 1996; 43: 99.

13. Ksiazyk J. Badania nad metabolizmem energii w nadciśnieniu wrotnym u dzieci. Assistant Professor's dissertation 1996.

14. Pawłowska J. Model opieki nad dzieckiem z niewydolnością wątroby. Assistant Professor's dissertation 1999.

15. Socha P. Efekty biochemiczne i kliniczne różnych metod wyrównywania niedoboru wielonienasyconych kwasów tłuszczowych u dzieci z cholestazą. Assistant Professor's dissertation 2002.

16. Thomas BJ, Cornish BAH, Ward LC Bioelectrical impedance analysis for measurement of body fluid volumes: a review. J Clin Eng 1992; 17: 505.

17. Chumlea WC, Gua SS. Bioelectrical impedance and body composition: present status and future directions. Nutr Rev 1994; 52: 124 .

18. Lehnert M, Clarke D, Gibbons J, et al. Estimation of body water compartments in cirrhosis by multiple-frequency bioelectricalimpedance analysis. Nutrition 2001; 17: 1.

19. Reilly J. Assessment of body composition in infants and children. Nutrition 1998; 14: 821.

20. Lukaski HC. Methods for the assessment of human body composition: traditional and new. Am J Clin Nutr 1987; 46: 537.

21. Moukarzel AA, Najm I, Vargas J, et al. Effect of nutritional status on outcome of orthotopic liver transplantation in pediatric patients. Transplant Proc 1990; 22: 1560-3.

22. Ryzko J. Zaburzenia metabolizmu witaminy D w przewlekłych chorobach wątroby u dzieci. Assistant Professor's dissertation. Warszawa 1991.

23. Sokol RJ, Heubi JE, lannaccone S, et al. Mechanism causing vitamin E deficiency chronic childhood cholestasis. Gastroenterology 1983; 85: 1172. 